\title{
RACIAL ISSUES AND THEIR INFLUENCES ON THE CHARACTERS IN SHAKESPEARE'S OTHELLO
}

\author{
Arfian Giri Prabowo
}

\begin{abstract}
INTISARI
Penelitian ini bertujuan untuk menjabarkan isu-isu rasial yang ditemukan dalam drama Othello dan menganalisa pengaruh isu-isu rasial tersebut terhadap karakter yang ada dalam naskah drama Othello. Dalam menemukan isu-isu rasial tersebut, penulis menganalisa dialog antar karakter dalam drama baik secara implisit maupun eksplisit.

Penulis menggunakan pendekatan objektif Abrams dan beberapa referensi untuk mengklasifikasikan isu- isu rasial serta tokoh-tokoh dalam drama tersebut berdasarkan tipetipe rasisme antara lain rasisme individual, rasisme pasif, rasisme aktif, dan internalized racism. Data penelitian ini diperoleh dengan cara menganalisa naskah drama Othello tanpa terpengaruh oleh informasi di luar teks tersebut.

Hasil dari penelitian ini menunjukkan bahwa di dalam drama ini terdapat isu-isu rasial. Hal ini mempengaruhi cara pandang tokoh-tokoh dalam drama termasuk Othello, terhadap orang kulit hitam. Sebagai akibatnya, Othello menjadi rasis terhadap dirinya sendiri dan kehilangan kepercayaan dirinya sebagai orang kulit hitam yang berakibat kepada kehancurannya.
\end{abstract}

Kata kunci: Isu-isu rasial, Pengaruh, Kehancuran Othello

\begin{abstract}
This study aims to describe the racial issues found in Othello and to analyze the influence of the issues on the characters in the play. In finding racial issues, the present writer analyses dialogues between the characters in the drama implicitly and explicitly.

The author uses Abrams' objective approach and also some references to classify the racial issues and along with the characters based on the types of racism such as individual racism, passive racism, active racism, and internalized racism. The data were obtained by observing the play without being influenced by materials outside of the text.

The result of this study indicates that there are racial issues in this play. The racial issues have a very significant effect on the characters' view, including Othello's, of the existence of black people. Othello becomes racist against himself and loses the confidence of being black, hence the cause of the fall of Othello.
\end{abstract}

Keywords: Racial issues, Influences, Fall of Othello 


\section{INTRODUCTION}

Othello is one of William Shakespeare's masterpieces which was written around 1603 and was first performed on November 1, 1604 in England. This play has become a phenomenal play throughout the world. The major character in this play; Othello, a noble Moor military general in the service of the Venetian state, was one of the first black heroes in Western literature (Othello). This play is controversial because Shakespeare chose a Moor, referring to black people in Africa, to be the main character of the play in the time when African slave trade was just beginning to be known and practiced in Europe especially in London.

The play Othello brought up an interracial marriage issue between the Moor and the White. Othello married a Venetian lady, Desdemona, who is a white skinned lady, but unfortunately this interracial marriage could not be saved because of the conflicts within such as jealousy and racial sentiment. Tragically their marriage ends with the death of both of them.

At the beginning of the play, it seems that it is about the elevation of black people for the Moor here is an honorable military general who is helping the Venetian state in the battle field against its

enemy, however, the present writer finds that this noble Moor experiences a tragedy in his life, the betrayal of his own ensign and suspicion that Desdemona is unfaithful. It is an irony in this play where such a great and honorable general does not have a peaceful life like the whites do.

Shakespeare managed to manipulate the reader's view toward Othello, to be unconsciously a racist reader through the main character's tragedy and see him as a fool at the end of the play for killing Desdemona, his own wife. Thus, this play is an interesting play to study as the present writer believes that the play is not merely about jealousy and revenge but also racial issue. In this paper the present writer conveys the racial issues found in the play and shows that these issues take part in building the flaw of the main character.

\section{RESEARCH METHOD}

The discussion of this research is limited to the observation of the text such as determining the racist characters in the play by finding and observing the racial utterances or gestures either implicitly or explicitly.

This study deals with the characterization of some regarded racist characters in the play; Othello, Iago, Rodergio, Duke of Venice, Brabantio, and Emilia and the analysis of parts of the text which are considered racist. The characters are analyzed to find their functions and how they influence the characters' view of the main character.

In order to achieve the objectives of this study, the objective approach is applied in analyzing the play. The objective approach puts an emphasis on the analysis of the literary work itself, eliminating external aspects of the text.

In analyzing a work of art using this theory, the reader is to interpret the text spoken by personas (narrator or speaker) and to find the significant parts of the text and how these parts contribute to the building of the theme of the play. The readers then should be able to see the value of the text and define which characters support the theme which in this case is racial issues. This consideration includes the kind of symbols used or the terms refering to the statements spoken by a speaker. By finding this information in the text using objective approach the present writer could define the theme of the play excluding the author, the readers and the social political environment at the time the play was written.

This research aims to show the indication of racism seen from the statements made by the characters in the play. The data are collected through library research, internet research and the primary data are taken from close reading of the text 
itself. Close reading is carried out to find statements in the play which are considered as expressions of racial sentiment which is the main discussion of the paper.

The present writer sees that the racial issues are significant issues found in the plot of this play and are considered to be an important factor of the tragedy that befalls the main character.

The statements which are considered as racial issues are then analyzed to find how these issues influence the main character's life seen through the actions he makes as a reaction of the problems he faces.

\section{The Theory of Character and Characterization}

Some characters in a play do not change, as stated by Christopher Russell Reaske;

They begin as the same kinds of characters as they are in the end. These passive characters are acted upon by the events of the play: they are usually static or unchanging. Conversely, some characters are active, they perform acts, they have large parts in the play, and they usually undergo certain changes as a result of the action of the play. Instead of being static, they are considered dynamic. Most of the heroes of great tragedy are dynamic characters. (43-44)

In Othello, Desdemona is the only static character, unchanged in her outlook and disposition, less affected by the changes happening around her. She appears at the beginning as an innocent lady and stays that way until the end of the play. The rest of the characters are considered as dynamic characters as they change their views, emotion, faith and etc.

In analyzing the characters, the readers should be able to convey as much information as possible regarding to the characters. This information could be the age, gender, educational background, social rank, religious belief, occupation, health, physical appearance, origin, etc. of a character where the readers then use this information to picture the nature of the character. In addition, as Dickinson stated, a character in a literary work can be characterized in several ways;

Firstly, by learning the author's statements (narration), secondly, by focusing on how and what characters talk about, thirdly, by understanding the action taken by the character, fourthly, by knowing the reaction of other character towards another. (14-16)

In this play Shakespeare prefers to reveal information about the play and his characters through their speeches and actions and by the descriptions of others rather than informing it through a narration. There are some methods used by the authors in giving the information about his characters in a play i.e. showing and telling. The one that Shakespeare uses in characterizing his personas in Othello is showing method; through what they say and do from which the readers will understand the nature of the characters as stated by Abrams;

In showing (also called 'the dramatic method'), the author merely presents his characters talking and acting and leaves the reader to infer what motives and dispositions lie behind what they say and do. In telling, the author himself intervenes authoritatively in order to describe, and often to evaluate, the motives and dispositional qualities of his characters. (21)

Minor characters in Othello like Brabantio, Roderigo, Emilia and the others share important ideas regarding the main character and through these supporting ideas the main character's traits can be unfolded. However, the most important is that the main character's own ideas about himself will show his real traits as the dialogues and actions in a literary work are the manifestation of the character, stated by Robert Stanton as "the most important evidence of all is the character's own dialogue and behavior. In good fiction, every speech, every action is not only a 
step in the plot but also a manifestation of character." (18)

\section{Racism, Racist and the Types of Racism}

According to Cambridge Advance

Learner's Dictionary racism is defined as "the belief that people's qualities are influenced by their race and that the members of other races are not as good as the members of your own, or the resulting unfair treatment of members of other races."

Racism means always looking down at other races' members and appraises one's own race as better than the others' thus resulting in the unfair treatments to others' race as one will consider his/her race is more important than others'. Futher, Martin N Marger explained that

Racism is the belief that humans are divided into distinct hereditary groups that are innately different in their social behaviour and mental capacities and that can therefore be ranked as superior or inferior. (27-28)

According to Simpson and Yinger "the physical types or characteristic that distinguish one race from another can be distinguished: skin pigmentation, nasal index and lip form, and the color distribution and texture of body hair." In Othello, the physical types of Othello can be clearly seen from his appearance which is described with terms such as black, thick lips, fierce and so on. These basic ideas of racism create borders among humans where they cannot accept races other than their own to be regarded as the same as theirs, caused by the opinion thatone race is superior and different from the others. The superior and inferior classification influences one race in judging the traits that other races posse, resulting in prejudice and unfair treatment to the so called inferior human races.

Racism, according to James $\mathrm{M}$. Jones, a social psychologist, is "the result of the transformation of race prejudice and/or ethnocentrism through the exercise of power against a racial group defined as inferior, by individuals and institution with the intentional or unintentional support of the entire culture." (117)

In Othello, this belief is embraced by some white people and exercised against the black, in this case, in the opinion on the match between Othello, a black person, and Desdemona, a white person. The racists consider the quality of their white race is higher than the black's, resulting in disagreements regarding the match, as for them to marry a black person abuses the quality of their race.

A racist is the believer of racism. A racist treats other races unfairly as s/he believes that his/her race is better than others' which leads to social conflicts among the people in the society. The existence of racists in the Othello is very important for the development of the story. The story develops through the conflicts between the characters in the play and the racists play an important role in creating conflicts based on racial issues to move people towards a certain condition they want. Their motivation in doing so is because they are simply racist and believe that their race is better than others'.

Marger explained in his book; "racist thinking presumes that differences among groups are innate and not subject to change. Intelligence, temperament, and other primary attitudes, beliefs, and behavioral trait are thus viewed as not significantly affected by social environments."

In a racist's mind, the human traits such as "intelligence, temperament and other primary attitudes are not significantly affected by social environments and they are not subject to chance." As a result, the racists will never accept the other races, the subjects of racism, as equal with them. This condition creates an eternal conflict between the racist and the subject of racism when the subject of racism trespass their border such as to be the part of the racist's race by interracial marriage, in this case the marriage between Othello and Desdemona. 
Racism is a complex matter, and it is not easy to define as it deals with an abstract concept human cannot see, which is a belief. For years scholars have elaborated the terms, definitions, and types of racism in order to provide a vivid understanding of racism. James M. Jones in his book Prejudice and Racism, categorized racism into nine categories.

\section{a. Individual racism}

Individual racism is defined as;

One who considers the black people as a group (or other human groups defined by essential racial characteristics) are inferior to whites because of physical (i.e., genotypical and phenotypical) traits. He or she further believes that these physical traits are determinants of social behavior and of moral or intellectual qualities, and ultimately presumes that this inferiority is a legitimate basis for that group's inferior social treatment. An important consideration is that all judgments of superiority are based on the corresponding traits of white people as norms of comparison. (417)

\section{b. Institutional racism}

Institutional racism is defined as "those established laws, customs, and practices which systematically reflect and produce racial inequalities... If racist consequences accrue to institutional laws, customs, or practices, the institution is racist whether or not the individuals maintaining those practices have racist intentions. Institutional racism can be either overt or covert (corresponding to de jure and de facto, respectively) and either intentional or unintentional." (438)

\section{c. Cultural Racism}

The third category of racism is cultural racism. This racism includes individual and institutional racism and one culture towards another. Jones defines cultural racism as

The cumulative effects of a racialized worldview, based on belief in essential racial differences that favor the dominant racial group over others. These effects are suffused throughout the culture via institutional structures, ideological beliefs, and personal everyday actions of people in the culture, and these effects are passed on from generation to generation. (472)

\section{d. Passive racism}

Passive racism is "a belief, attitude, and actions that contribute to the maintenance of racism, without openly advocating violence or oppression. The conscious and unconscious maintenance of attitudes, beliefs, and behaviors supports the system of racism, racial prejudice, and racial dominance." (Adams 89)

\section{e. Active racism}

Active racism is defined as an "actions or statement which have implicit or explicit goal to the maintenance of the system of racism and the oppression of those in the targeted racial groups. People who participate in active racism advocate the continued subjugation of members of the targeted groups and protection of 'the rights' of members of an agent group. These goals are often supported by a belief in the inferiority of People of Color and the superiority of white people, culture, and values."(Adams 89)

\section{f. Social Racism}

Social racism comprises racist beliefs, attitudes, and stereotypes widely shared within a given population and expressed in cultural and social modes such as religion, popular entertainment, advertisement, and other media.

This kind of racism occurs in a group of society where beliefs, attitudes, and stereotypes are shared among them, and apparently have become a society's norm. All the members of the society comprise these racist ideas with the support of the local media information. The society will reject the racial subjected person or group into their society, maintaining only a single race in the society in their everyday activities.

\section{g. Horizontal racism}

Horizontal racism is explained in a source book entitled Teaching for Diversity and Social Justice as 
"the result of people of targeted racial groups believing, acting on, or enforcing the dominant (White) system of racial discrimination and oppression. Horizontal racism can occur between members of the same racial group (an Asian person telling another Asian wearing a sari to 'dress like an American'; a Latino believing that the most competent administrators or leaders are white, Native Americans feeling that they cannot be as intelligent as Whites, Asians believing that racism is the result of People of Color not being to raise themselves "by their own bootstraps"". (Adams 98)

\section{h. Reverse Racism}

Reverse racism is "a term created and used by white people to deny their white privilege. Those in denial use the term reverse racism to refer to hostile behavior by people of color toward whites, and to affirmative action policies, which allegedly give 'preferential treatment' to people of color over whites."(Butler)

\section{i. Internalized racism}

This type of racism is explained by Donna Brivens as "the situation that occurs in a racist system when a racial group oppressed by racism supports the supremacy and dominance of the dominating group by maintaining or participating in the set of attitudes, behaviors, social structures and ideologies that undergird the dominating group's power."

Brivens further explains that internalized racism has an impact on how the white people name the problem "there is a system in place that misnames the problem of racism as a problem of or caused by people of color and blames the disease - emotional, economic, political, etc. - on people of color. With internalized racism, people of color might, for example, believe they are more violent than white people and not consider state-sanctioned political violence or the hidden or privatized violence of white people and the systems they put in place and support". With this kind of racism, the people of color become the subject to blame upon the problems in life, and it creates the images that people of color is violent. (1995).

\section{RESEARCH RESULT Characters}

Not all of the characters in Othello are racist, therefore, the analysis will be focused on the regarded racist characters i.e. Othello, Brabantio, Roderigo, the Duke of Venice, Iago and Emilia.

\section{a. Othello}

Othello is the main character of the play; he is a black man, a Moorish, a tribe from the decent Africa. He is a military general who came to Venice as the request of the State which needs him to help the state to lead the war in Cyprus against the Turk. During his time in Venice, Othello falls in love with the Senator's daughter, Desdemona, a white young Venetian girl. Their marriage leads to the conflict in his life and himself for interracial marriage at that time is still considered taboo by some people.

Othello is known as a soft spoken black man. It is seen when Brabantio and his party siege him with the sword, he faces it calmly and said;

OTHELLO. Keep up your bright swords, for the dew will rust them.(I, ii, 60)

Othello describes himself as a man who can change his nature and become stupid when he is perplexed and wrought;

OTHELLO. .... Of one not easily jealous, but being wrought

Perplex'd in the extreme; of one whose hand,

Like the base Indian, threw a pearl away

Richer than all his tribe;... (V, ii, 345347)

Iago describes Othello as one who sees people as they look, or simply from the appearance.

IAGO. The Moor is of a free and open nature,

That thinks men honest that but seem to be so,

And will as tenderly be led by the nose 
As asses are. (II, i, 405-407)

In fact, Othello only trusts Iago and this statement does not fit Othello. As the play progresses, it can be seen that he is an introvert person who keeps everything in his mind even from the beginning when he wanted to marry secretly. Othello is a protagonist even though he kills his honest wife at the end of the play and then kills himself.

\section{b. Brabantio}

Brabantio is the father of Desdemona, a white Venetian lady who falls in love with a black person from the Moorish, tribe in Africa. He is an aged man, who has ruled the city for years as the Lord Mayor of the city of Venice;

\section{OTHELLO}

Good Signior, you shall more command with years

Than with your weapons. (I, ii, 61)

"...that I have ta'en away this old man's daughter,

It is most true; true, I have married her;...” (I, iii, 77-79)

Othello tells Brabantio that he would respect him and obey his order as Brabantio has been a distinguished noble man, a Signior of Venice, for a long time. Thus, a noble man such as Brabantio does not need a weapon to make Othello follow his words but rather his rank and age. His status and seniority is also admitted by Iago;

beloved,

...That the magnifico is much

And hath in his effect a voice potential As double as the Duke's.

He will divorce you, Or put upon you what restraint and grievance

The law, with all his might to enforce it on, Will give him cable. (I, ii 1214)

Here Iago states that the Magnifico, that is Brabantio, is very much beloved by his citizens and his voice is two times more powerful than the Duke's even the law of the state would allow him to do in his own will. From the line we could see how powerful Brabantio is and what a good leader he is as he is very popular among the Venetians.

DUKE.Whoe'er he be that in this foul proceeding

Hath thus beguiled your daughter of herself

And you of her, the bloody book of law

You shall yourself read in the bitter letter,

After your own sense, yea, though our proper son

Stood in your action. (I, iii, 65-69)

From those lines the present writer then takes Brabantio as the representative of Venetian people as he is beloved and his voice is very powerful therefore his words would be the Venetian's as well.

In the play, it can also be seen that Brabantio is a good and warm man; he often invites Othello to have dinner together with him in his house. As the leader of the city, Brabantio treats his guests very honorably by not only inviting him to his dinner but also sharing stories altogether with his family.

OTHELLO. Her father loved me, oft invited me,

Still questioned me the story of my life From year to year, the battles, sieges, fortunes,

That I have passed. (I, iii, 128-131)

On the other hand, Brabantio is racist as well, as he does not agree with interracial marriage. He is very angry and dismayed at the moment he finds his daughter not in her chamber, but eloping with the Moor.

Brabantio even states that it is better to adopt a child than to have one married to a Moor. However he is apparently a liberal parent for allowing to the members of his family to gather with anyone including the Moor. However, then his nature changed (to became protective) when he finds his daughter secretly married to the Moor. And if he has other children, he would not let them go out from their rooms. 
DUKE.If you please, Be't her father's. (I, iii, 240)

BRABANTIO. I'll not have it so. (I, iii, 243)

His nature changes from love into hatred. Brabantio died in his grief at the end of this play because of the interracial marriage, this indicates that racial issue is very significant in his life. Although he appears only at the beginning of the play, this character changes significantly from a delightful father for having a social rank, wealth, security and also a blissful family; a loyal wife and an obedient daughter, all turn around into the feeling of sorrow and grief until the end of his life.

\section{c. Roderigo}

Roderigo is a rich Venetian gentleman madly in love with Desdemona. He pays Iago to help him to win her hand as the father has refused his deed.

BRABANTIO. I have charged thee not to haunt about my doors

In honest plainness thou hast heard me say

My daughter is not for thee. (I, i, 96-99)

Roderigo appears in the first scene of the play and is disappointed at knowing that Desdemona marries Othello, the black General hired by the Venetian state, while he has spent his money to pay Iago who promises him Desdemona's love.

Roderigo plays an unimportant role in the play, for even without his presence, Iago himself is still able to create the plot of the story, but the present writer believes that the existence of Roderigo here is to deliver a message about racial issue as he is the first man talking racist;

RODERIGO. What a full fortune does the thicklips owe

If he can carry't thus!. (I, i, 66)

Roderigo does not change his nature from the beginning of the play until the end. He remains short minded and easy to manipulate.

\section{d. Emilia}

Emilia is wife to Iago. They have been married for some time before the play begins. Emilia is Venetian as well as Iago, asked by Othello personally to come along to Cyprus to accompany his new wife, Desdemona, and provides her needs. She is a silent woman as Desdemona said;

DESDEMONA. Alas, she has no speech!, (II, i, 103)

This denies what Iago's description of her that is a talkative woman. In contrary, Iago describes his wife as a chatty woman;

IAGO. Sir, would she give you so much of her lips

As of her tongue she oft bestows

on me,

You'll have enough. (II, i, 104-

Iago describes his wife as so after Cassio (Othello's second in command) kisses her on the lips ( a sign of superiority in rank, a tradition) that he might be pleased because of kissing her, but not listening to what she has to say. Iago also admits that his wife is chatty just before bed time;

IAGO. In faith, too much.

I find it still, when I have leave to sleep. (II, i,104-105)

These lines tell us that Emilia is an introvert woman who speaks freely only to the one she has already known well, that is, Iago, as well as under certain circumstances.

Emilia is a loyal wife, preferring her husband than anyone else, even though she knows the fact that Desdemona will go mad for losing the handkerchief but still she helps her husband, Iago,

EMILIA. If it be not for some purpose of import

Give't me again: poor lady

She'll run mad when she shall lack it. (III, iii, 316-318)

IAGO. Be not acknownon 't, I have use for it,... (III, iii, 319)

Emilia lied to Desdemona about the handkerchief when she asks whether she knows where her handkerchief is, and she replies "I know not, madam" instead. 
On the other hand, Emilia is a pathetic person who does not want to get involved into something too far and burdens her thought with something other than her business. Through her reaction when finding the handkerchief and handing it to Iago, it can be seen that she does not think further about what he will use the handkerchief for.

$$
\text { e. Iago }
$$

$\mathrm{He}$ is a twenty eight year old Venetian man married to Emilia. Iago is Othello's ensign who desires the lieutenancy position. $\mathrm{He}$ is the antagonist character of the play as well as the narrator, who knows everything and the things that are going to happen. Sometimes he speaks to himself, a monologue where it could be the time he speaks honestly. Very talented and relentless in manipulating other characters seem to be his nature. In addition, Iago has the ability to understand the nature and the way of thinking of the other characters, which makes it easier for him to manipulate them. Iago plays a very important role in the play, creating the conflicts which make the play interesting. $\mathrm{He}$, however, is the master of punning words that change anger to pity, distrust to believe and false to honest hence he always manages to avoid being blamed.

Iago is the villainous character in this play, all the advices he gives and the words he speaks are used only to manipulate the other characters to work out his plan. He is also the one who brings up racist sentiment in the play and influence the other characters to be racist as well.

$\mathrm{He}$ is a cold blooded murderer. $\mathrm{He}$ kills Roderigo for his own benefit. Othello describes Iago as a devil;

OTHELLO. I look down towards his feet; but that's a fable.

If that thou best a devil, I cannot kill thee. (V, ii, 286-287)

\section{f. Duke of Venice}

The Duke is the authority in Venice. $\mathrm{He}$ is the chairman of the parliamentary and has a right to decide the important decisions for the country, such as war declaration. The Duke appears only in a few scenes in this play, yet he has a great influence on the story.

As a person who is responsible of the welfare of the country, the Duke of Venice is a very cautious person, as seen on the following lines

"Nay, it is possible enough to judgment:

I do not so secure me in the error,

But the main article I do approve

In fearful sense." (I, iii, 10-12)

Obtaining inaccurate reports about where the enemy might attack, the Duke chooses not to be in a rush in taking the decision to send his army to defend his region from the attack. He decided to wait for the accurate information from the informer in order to take a right decision. In addition, $\mathrm{He}$ is also a fair one in making a decision, as seen in the lines;

"To vouch this, is no proof,

Without more wider and more overt test Than these thin habits and poor likelihoods Of modern seeming do prefer against him." (I, iii, 106-109)

\section{Racial Issues and Racist Characters}

The play emphasizes on Iago's effort in ruining the marriage between Othello and Desdemona from the beginning until the end of the play. It shows how crucial the interracial marriage is, for Iago and the other Venetians. The present writer analyses these issues found in the play as an evidence of cultural threat of interracial marriage felt by Venetians. The racial sentiment affects the characters' views and behavior toward Othello. This condition also has an effect on Othello which makes him insecure because of his blackness.

The existence of racist characters in this play is very significant to the development of the story. These racist characters bring up the issues of race, creating the border between races to distinct their superiority and inferiority. Their goal is to affirm which kind of rights one race deserves or does not deserve. Othello highlights the interracial marriage of Othello and Desdemona as something that a racist society cannot accept. 
Therefore, some racists in this play tried to take actions perceiving the trespassing of the border of race while some others chose to react passively.

\section{a. Brabantio}

When Brabantio heard from Iago that Othello had robbed him, he indicted Othello as a thief for the criminal act he committed which is stealing his daughter. The use of the word "thief" characterizes Othello as a bad person and a morallycorrupted person, taking other's belonging without permission. In addition, the word "steal" and "stow'd" used by Brabantio depict that the leaving of Desdemona is not because of her own will but Othello's wrongdoing, kidnapping her and hiding her somewhere.

O thou foul thief, where hast thou stow'd my daughter?

Damn'd as thou art, thou hast enchanted her,

For I'll refer me to all things

of sense,

If she in chains of magic were not bound,

Whether a maid so tender, fair, and happy, she shunn'd

So opposite to marriage that of our nation,

The wealthy, curled darlings

Would ever have, to incur a general mock,

Run from her guardage to the sooty bosom

Of such a thing as thou- to

fear, not to delight. (I. ii. 62-71)

Brabantio further suggests that Othello had enchanted Desdemona by using magic to trick her into marrying him. He considers, marrying a black man cannot be accepted logically because the essence of marriage is to find happiness by marrying an eligible man that she loves that is a man of rank, wealth, and race. Desdemona has shunned marriage even to the most wealthy and eligible men of the society thus incurring mockery from the society. On the other hand, she chooses to marry the "sooty bosom" Othello, a black person of inferior race. The racist Brabantio refers to Othello as "a thing to fear", dehumanizing a person by equaling him to "a thing to fear, not to delight". The word "thing" here refers to an inanimate material object as distinct from a living being (Oxford English Dictionary 11th Edition).

Brabantio continues to express his prejudice and racism by accusing Othello of practicing black magic, using charms like drugs or minerals to abuse Desdemona and win her hand eventually. Brabantio does not want to see the possibility of love occurring between them but his eyes are blocked by these racist feelings and the negative prejudice about black people. Brabantio considers it "gross" for a white lady to fall in love with an old black person without the influence of foul spells. The image of devilish, mentally corrupted people, frightening, and practice of witchcrafts are some characteristics that white people often relate to black people. As a result, Brabantio accuses Othello based on the negative images of the black people that he has in mind instead of on proven evidences.

To prison, till fit time of law and course of direct session

Call thee answer.

Based on the definition of racism, Brabantio is a racist because the excerpts show that he believes that Othello in an inferior even though he is an army general. This is due to the race he belongs to. This is also a consideration of which kind of session Othello will be tried. belongs to the inferior race while Brabantio's is superior, he puts aside Othello's rank as a general army but putting up Othello's inferior race as consideration of which kind of session Othello will be courted.

Brabantio belongs to an individual active racist as he shows or expresses his racist feeling to the subject of racism, that is Othello, explicitly. Brabantio abuses Othello by saying that he is a black magic practiser. However, Othello does not 
affected by the racist slur said by Brabantio.

b. Roderigo

In Elizabethan era, the marriage between a black and white couple is unacceptable. Black people are stereotyped as evil and so on. At that time, the majority of Venetians found the interracial marriage between black and white was not common. Roderigo even said that Othello will be very fortunate if he can maintain the marriage.

What a full fortune does the thick lips owe if he can carry thus (I. i. 66)

$\mathrm{He}$ believes that it is only fortunate for Othello to win Desdemona. In his statement he uses a racist commentary using the words "thick lips" which refers to black people. Roderigo doesn't consider Othello's rank as a general army helps him in winning Desdemona's hand but only the sheer of luck. For Roderigo, his rank does not mean anything as long as his skin is black Roderigo believes that Othello cannot save his marriage, despite his rank and wealth. It is his race which raises the deadlock conflict in his household. With the faith he has, Roderigo continues his effort to win Desdemona even though he has only wealth. The most important thing for him is that he is white like Desdemona.

Roderigo belongs to a personal active racist as he believes personally that Othello, a black person, possesses lower degree of intellectual and capability to maintain his marriage with Desdemona. Even though Othello is a general army who helps Venetian to fight their enemy, Roderigo as a Venetian still regards Othello as a "wheeling stranger" showing that the acceptance of the Venetians of Othello is only temporary. When his duty to Venetian state is done, the acceptance of the Venetian of him will be over as well.

Roderigo is also regarded as an active racist who expresses his racist feeling and takes action to get rid of the racist targeted person, Othello. According to the previous discussion, after Roderigo expresses his racist feeling by calling
Othello "thick lips", he further wakes up Desdemona's father, Brabantio' as an attempt to break up the interracial marriage. This action is done because of the racist feeling he feels towards Othello. $\mathrm{He}$ believes that a black man such as Othello does not deserve the white maiden Desdemona.

c. Emilia

After knowing that Othello kills Desdemona, Emilia cries to Othello if he is now the "blacker devil" for killing Desdemona.

OTHELLO: She's, like a liar, gone to burning hell:

'Twas I that kill'd her.

EMILIA: O, the more angel she, (V.ii.36)

And you the blacker devil!

Emilia is portrayed as a racist at the end of the play, but in fact, Othello is always seen as a black devil by Emilia as she says that Othello is a "blacker devil" after killing Desdemona. This means that previously he was black and after killing Desdemona he becomes blacker. In Emilia's eyes Othello is a devil which connotes immorality, violence and something that human should avoid in life.

Emilia is categorized as; individual, passive, unconscious racism to active racism. These types of racism change one to another depending on her condition. Firstly, she does not show a significant feeling of racist before she knows that Othello has killed Desdemona, her mistress. In some scenes of these plays Emilia seems to have less contact with Othello. She prefers to be passive and hide her racist feeling. This is considered as passive racism because Emilia tends to hide her racist feeling which is the characteristic of passive racism. Emilia is also considered to possess individual racism for she believes that Othello is a black devil until he kills Desdemona then he becomes a blacker devil. The racist feeling of Emilia is shown when she finds Desdemona on her bed, killed by Othello. Her uncontrolled feeling for the death of her mistress causes 
her to be racist to Othello unconsciously. The critical condition moves her from passive racist to active.

\section{d. Iago}

Iago uses very rough words to wake Desdemona's father up from his sleep at night. For Iago, the relationship between Othello and Desdemona is not based on the logical thinking of both of them but lust, just like what animals do when finding their spouses. Therefore, Iago compares them to animalistic imageries which are old black ram for Othello and a white ewe for Desdemona.

Even now, now, very now, an old black ram

Is tupping your white ewe. Arise, arise; Awake the snorting citizens with the bell, Or else the devil will make a grandsire of you.

Arise I say! (I. i. 99-92)

This comparison is based on how white people in Elizabethan era enslaved black people and treat them like animals. Thus, Iago uses the animals to describe Othello and Desdemona as his suitor. The use of animalistic imagery to describe both Othello as well as Desdemona is to make Brabantio realize that his daughter has degraded her morality. Eloping with Othello means that she does not put forward the logical thought but merely lust and passion. In addition, Black people in this era were considered as having hyper sexuality and an animal -like by most of the current society member. Hence Iago insists Brabantio to wake up the sleeping citizen as he thinks that this interracial marriage will be denied by the society. Moreover, Iago also shows the consequence Brabantio will face if he does not react quickly to the eloping of his daughter; he states that the "devil" will make a grandsire of you. He uses the imagery of devil to portray Othello where devil connotes black, cruel and everything which is bad. He compares the black person with the devil and anything which is bad and of course the white people with the angel.
Because we come to do you service and you think we are ruffians, you'll have your daughter covered with a Barbary horse; you'll have your nephews neigh to you; you'll have coursers for cousins and gennets for germans. (I. i. 109-113)

Iago stresses on the animalistic imagery of black Othello as "Barbary horse", the kind of horse that can only be found in the desert in Africa which is known for its strength, endurance, wildness, and high passion of sex. Iago is very racist after all; the match of Desdemona to Othello will not increase the negative stereotype attached to Othello but decrease the rank of Desdemona as a white maiden, as she will have children of animals by marrying "a Barbary horse".

To play with the Moor's intelligence is also the way he used to succeed in his plan of ruining Othello's marriage. He believes that "The Moor is of free and open nature/ that thinks men are honest that but seem to be so,/ and will as tenderly be led by the nose as asses are" ( II, I, 405-408). The Moor, for Iago, is the person of less intelligent as he does not have an analytical thinking of what is happening around him even though he is a General army. As a result, his unawareness gives an opportunity to a person who wants to cheat him or even controls his life.

The previous discussion shows that Iago is an individual racist who is active showing his racist feeling to others and to the very Othello.

e. Duke of Venice

The duke and the senators are the authority of Venice, they agreed to ask Othello to lead the army against the Turk "Here is the man, this Moor, whom now, it seems, your special mandate for the stateaffairs Hath hither brought (I, iii, 70-73)". Both of them see Othello is different from the other black Moors thus they trust him to lead the army. However, the sentence below shows that Othello is an exception, he is the only black Moor who is respected 
and delegated to do a service for the Venetian state.

Good night to everyone, and, noble signior, If virtue no delighted beauty lack,

Your son-in-law is far more fair than black.' (I, iii, 22)

In these lines, the duke compliments Othello as he is "far more fair than black", means that if worthiness is a beautiful thing in itself, your son in low, though black, has beauty (Levin Richard 1960: 27). The Duke's compliment shows that he is racist anyway, because the black Moor that has beauty is only Othello, and again, Othello is the only exception. The duke doesn't see Othello as a black man anymore but as a black skinned white man. On the other hand, the duke's statement always also racist as he tried to calm Brabantio by saying that his son-in law will be far fair than black, it means that Brabantio doesn't need to worry if his son-in law is black.

The Duke of Venice experiences the passive racism where he believes that black people is less beautiful than white. Even though the Duke seemed to save Othello from the racist slur of Brabantio, his sentence is racist or at least support the racial dominance of white people because although Othello might be far more fair than black, still he cannot be equal to white people. Besides, the Duke's appraisal of Othello is shows that Othello is an exception of black person who has a virtue and good manner that differentiate him from the other black people.

Despite his rank as the duke of Venice, he does not provocatively show his racial prejudice which would cause institutional racism, preferring to be an individual passive racist. This might because the Duke needs Othello's help to defeat the Turks, mirroring to the hospitality of Brabantio which changes to anger when he finds that the black Othello is marrying his daughter.

\section{f. Othello}

Othello is a black person in the play thus being the target of racism, but he is racist anyway. $\mathrm{He}$ experiences an internalized racism, a condition where a racism-targeted person agrees with what racist people say about him relating to his negative images, behavior and morality. This condition might be caused by the immense and continuous racist attack, to the target of racism by the society, forcing him to believe of what racist, say.

... Her name, that was as fresh

As Dian's visage, is now begrimed and black

As mine own face... (III. iii.54)

For Othello, Desdemona was like a roman goddess, Diana or Dian, goddess of the moon symbolizing fertility and hunt. The goddess is pictured as a beautiful woman with a shining pale face like the moon's light.

This sentence shows that Othello is very disappointed at Desdemona as she is not like what he predicted before. $\mathrm{He}$ changes his mind about Desdemona after Iago tells a lie about her having an affair with Cassio, Othello's lieutenant. Therefore, the beautiful image of Desdemona changes into something bad and disgustful, Othello's own face. Othello contrasts the moon shining face of Desdemona to the blackness of his own face which is begrimed and not admirable. Unconsciously he is racist to himself by mocking his own blackness as a disgusting thing.

Othello ruins his confidence of being black when he knows that Desdemona has become unfaithful by having affair with Cassio, a good looking Florentine. Iago tells false information about Desdemona in order to make Othello believes that a black person is not created to be the spouse of the white person.

" Haply, for I am black

And have not those soft parts of conversation

That chamberers have, or for I am declined

Into the vale of years - yet that's not much - " ( III, ii, 263-166)

Othello implicitly admits that he is not derived from the intellectual race as he 
thinks of his not having a charming speech that could make woman comfortable staying beside him. He looks down to himself and filling his mind with negative probable reasons of why Desdemona cheated him.

An internalized racist does not believe in his own ability and considers a person from another race is more intelligent.

"Why did I marry? This honest creature doubtless

See and knows more, much more, than he unfolds." (III, iii,141-142)

Othello thinks that Iago is a very intelligent person, he has a deeper analysis on Desdemona's behavior. He even questions about his decision to marry Desdemona and he might regret why he did not ask for consideration from Iago before he marries.

\section{CONCLUSION}

According to the previous discussion, there are racial issues found in the play. Some characters of the play are racists either implicitly or explicitly. Roderigo and Iago are active racists since the play starts. They show their racist feeling and bring up the racial issues by uttering "thick lips", "old black ram", "white ewe", "barbary horse", "gross claps of a lascivious Moor", and other animalistic imageries which support the white supremacy. While the other characters, Brabantio, Emilia, and Duke of Venice, are passive racists as they hide their racist feeling or do not express violently to the racist targeted person. On the other hand, Brabantio and Emilia change from passive into active racist as the play continues. Their racist feelings are triggered by certain condition. Racism is also experienced by Othello, a black person, who eventually believes that his blackness cannot be accepted by the white society and considers himself as someone who is not intelligent and is unable to make decision. He then depends on the whites to make decision for him. Othello is and internalized racist whose actions or thoughts and beliefs support the white supremacy.

The racism in the play has a great impact on those characters and also on the fall of Othello. The characters in the play change their view towards Othello from a hero to an enemy as the racial issues that trigger their racist side treat Othello unfairly. They treat Othello not as a hero anymore but as an outsider of an inferior race that comes to Venice to abuse their superior race as Othello marries Desdemona. This treatment rises racism in Othello and throws away his self-esteem as a black general army, feeling inferior because of his blackness. This inferior feeling makes Othello a racist against himself and thinks that he is only like the other black people who are known to have negative images such as immoral, full of lust, and other negative images. On the other hand Othello was very sure that he is different from the other black people. He was even offended by the slur words set by Brabantio to him. As a result, Othello behaves like the other black people who think that white people are superior and racist. This causes Othello to have prejudice against Desdemona. He considers that Desdemona is not seriously in love with Othello but uses him to fulfill her passion. Because Othello experiences an internalized racism, he feels inferior and considers white people are more intelligent than him. Therefore he trusts Iago as a white person more than himself. $\mathrm{He}$ believes what Iago says about Desdemona being unfaithful to him thus he feels foolish for marrying Desdemona. Othello believes that the affair of Desdemona is caused by the blackness of his skin thus Othello decides to kill Desdemona. 


\section{BIBLIOGRAPHY}

Abrams, M. H. Mirror and the Lamp. New York: Oxford University Press. 1953.

---.. A Glossary of Literary Terms fourth edition. New York: New York: Holt, Rinehart and Winston. 1981

Adams, Maurianne., Lee Anne Bell, and Pat Griffin, ed. Teaching for Diversity and Social Justice : A Sourcebook.New York. Routledge .1997. PDF File

Dickinson, Leon T. A Guide to Litterary Study. New York : Rinehart and Company, Inc. 1959.

Butler, Shakti. "Diversity Facilitation Training". University of Delaware : Office of Recidence Life. 2007. PDF File

Craniford, Ada., Doug Craniford, and Eric Weinthal. A Taste of Shakespeare: Othello. Eugenia Educational Foundation. N.d. PDF File

Ikrarini, Estri Oktarena. Iago's Profile in Othello by William Shakespeare. Graduating Paper. UGM. 2005.

Jones, James M. Prejudice and Racism. Addison-Wesley Pub. Co. 1972.

Katelyn. "If virtue no delighted beauty lack,/ Your son-in-law is far more fair than black". Billy \& Bodies, March 2009. Web. December 2012. < http://www.102applegate.blogspot.co $\mathrm{m} / 2009 / 03 /$ if-virtue-no-delightedbeauty-lack-your.html>

Levin, Richard. TRAGEDY: Plays, Theory, and Criticism. Harcourt Brace Jovanovich, Inc. 1960.

"London and the Transatlantic Slave Trade". Portcities London. N.d. Web. August

2012.http://www.portcities.org.uk/lon don/server/show/ConNarrative.103/ch apterId/2245/London-and-thetransatlantic-slave-trade.html

Merritt, Dorrell. "Blemmyae / Anthropophagi”. October 2012. Web. December 2012.

http://sangbleu.com/2012/10/12/blem myes-anthropophagi/>
Marger, Martin N. Race and Ethnic Relations: American and Global Perspectives, Third Edition. Wadsworth Publishing Company. 1994.

MLA Handbook for Writers of Research Papers. 7th Ed. New York: The Modern

Language Association of America, 2009. Print.

Stanton, Robert. An introduction to Fiction. Holt, Rinehart and Winston. 1965.

Simpson, George E., and J. Milton Yinger. Racial and Cultural Minorities: An Analysis of Prejudice and Discrimination, 5th Edition. New York: Plenum. 1985. 